\title{
Produktivitas dan Faktor-Faktor yang Berpengaruh Terhadap Produksi Usahatani Tomat (Solanum lycopersicum Mill) di Kabupaten Jember
}

\author{
Bagus Rangga Sita ${ }^{1}$, Syamsul Hadi², dan Edy Sutiarso ${ }^{3}$ \\ Universitas Muhammadiyah Jember
}

\begin{abstract}
The purpose of this study include: 1)measuring the level of farm productivity and comparing among the tomato business scale, and 2) to identify factors that influence the tomato farm production in Jember. This research has been conducted in Jember, covering five District of samples, namely: Ledokombo, Sumberjambe, Ajung, Panti and Umbulsari. The data used are primary data and secondary data. Primary data were obtained from interviews with tomato farmers are guided by a list of questions that had been developed previously. While the secondary data obtained from the literature and agencies associated with this research. Analysis of the data used include quantitative descriptive analysis and regression naturally assuming that the relationship between the independent variables $(X i)$ and dependent variable $(Y)$ is a Cobb-Douglas production function. The final conclusion is that: 1) The average productivity of farming tomatoes in Jember district, which consists of land productivity amounted to $153.662 \mathrm{ku} / \mathrm{ha}$, labor productivity of $4.906 \mathrm{Kg} / \mathrm{JKP}$, and productivity costs by $0.00047 \mathrm{Kg} / \mathrm{USD}$. Based strata land area, did not show any differences in labor productivity and costs and but on land productivity among business scale narrow and wide, showed a highly significant difference in the confidence level of 99\%, and 2) the factors that affect significantly to namely the production of land, labor and seed, while the fertilizers, pesticides and pesticide effect no significant effect on farm production of tomatoes in Jember.
\end{abstract}

Keywords: Productivity, Production, and comparisons between the scale of farming

\section{PENDAHULUAN}

Sektor pertanian mencakup sub sektor tanaman bahan makanan, perkebunan, pertanian, perikanan dan kehutanan, di mana saat ini sektor ini menyumbang penyerapan tenaga kerja baru setiap tahunnya (40\%) dan masih menjadi tumpuan hidup bagi sebagian besar angkatan kerja di Indonesia, bahkan kebutuhan akan pangan nasional masih menumpukan harapan pada sektor pertanian (BIN, 2012). Sebagai negara yang memiliki dua musim, sebenarnya potensi Indonesia sebagai penghasil produk-produk unggulan hortikultura hampir tidak memiliki pesaing.

Corresponding Author:

Email : syamsul.hadi@unmuhjember.ac.id 
Artinya Indonesia memiliki kekayaan sumberdaya komoditas pertanian yang tinggi dan ketersediaan lahan pertanian lebih luas.

Besarnya potensi sektor pertanian ditunjukkan oleh kontribusinya terhadap PDB Nasional pada tahun 2010 sektor pertanian berkontribusi sekitar 956.120 miliar rupiah dan terus meningkat hingga pada tahun 2014 yaitu sebesar Rp. 1.128 .448 miliar. Kondisi ini mengindikasikan bahwa nilai PDB Indonesia selama periode tahun 2010-2014 mengalami peningkatan yang signifikan dengan rata-rata nilai PDB konstan di Indonesia tahun dasar 2010 mencapai Rp 7.721.032 miliar rupiah per tahun. Sementara itu, kontribusi tanaman hortikultura terhadap sektor pertanian selama periode tahun 2010-2014 mengalami fluktuatif, dimana pada tahun 2010 yaitu sekitar 11,55\% dan meningkat pada tahun 2011 yaitu sebesar 12,08\%, nilai kontribusi tanaman hortikultura termasuk tomat (Lycopersicon esculentum Mill.) terhadap sektor pertanian paling rendah, terjadi pada tahun 2013 dan 2014 yaitu sebesar 10,91\%, dengan rata-rata kontribusi sebesar 11,35 per tahun\%.

Produktivitas tomat di Indonesia mengalami fenomena yang berfluktuatif, dimana pada tahun 2010 mencapai 14,58 ton/ha dan pada tahun 2011 meningkat sebesar 16,65 ton/ha, namun pada tahun 2012 produktivitas tomat mengalami penurunan menjadi sebesar 15,75 ton/ha dan pada tahun 2013 produktivitas tomat kembali meningkat menjadi 16,61 ton/ha, akan tetapi pada tahun 2014 mengalami penurunan menjadi 15,52 ton/ha dengan tingkat pertumbuhan sebesar 1,93\% per tahun sebagaimana yang tampak pada Gambar 1 .

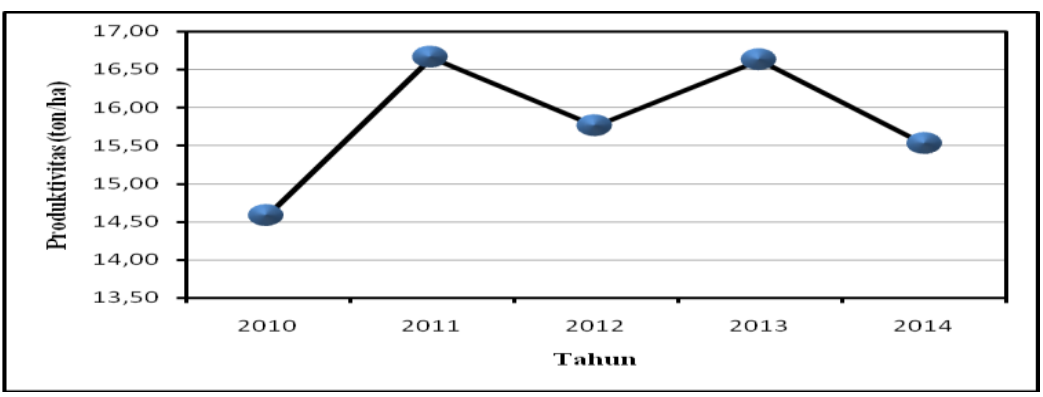

\section{Gambar 1. Perkembangan Produktivitas Tanaman Tomat di Indonesia Tahun 2010-2014 (BPS, 2015)}

Ternyata yang mengalami perkembanga yang fluktuatif bukan sekedar produktifitas tomat, tetapi perkembangan luas lahan dan produksinya mengalami fenomana yang sama pada periode yang sama (BPS, 2015). Hal ini ditunjukkan luas panen tanaman tomat pada tahun 2010 yaitu sebesar 61.154 ha mengalami penurunan penurunan sebesar $-1,26 \%$ pada tahun 2014 yaitu seluas 59.008 ha. Adapun produksi tomat pada tahun 2010 sebesar 891.616 ton, kemudian mengalami penurunan sebesar $-6,35 \%$ pada tahun 2014. Selama 
periode ini, Indonesia harus melakukan impor tomat dari Negara Malaysia, Thailand dan Singapura rata-rata sebesar 0,29\% (94 ton) dan Indonesia menjadi inportir tomat terbesar keenam di ASEAN, sedang Singapura menempati urutan pertama. Tetapi pada periode yang sama, Indonesia juga menjadi negara eksportir tomat di ASEAN meskipun memberikan kontribusi sebesar 3,05\% dari total volume ekspor tomat, dan Malaysia menjadi negara eksportir tomat nomor pertama di ASEAN yang kontribusinya mencapai 94,54\% (28.448 ton) (Deptan, 2015).

Sejalan dengan fenomena di atas, fakata menunjukkan bahwa ketersediaan pangan tomat tidak terlalu menjadi hal yang perlu dikhawatirkan meskipun seringkali terjadi kenaikan harga tomat cukup signifikan akibat kekurangan stok produksi. Tetapi yang terjadi pada tahun 2016 harga tomat di tingkat petani mengalami penurunan drastis dari Rp 45.000 / kg hingga menjadi Rp 500 - Rp 1000 per kilogram dalam hitungan beberapa minggu. Kondisi inilah yang patut dikhawatirkan akan berdampak pada lemahnya motivasi petani untuk kembali menanam tomat pada lahanya, sehingga dapat menguranya luas tanam dan produksi tomat. Kondisi turunnya harga tomat di tingkat petani ini terjadi hampir seluruh pelosok di Indonesia termasuk di Kabupaten Jember.

Menurut Dinas Pertanian Kabupaten Jember (2015) bahwa areal pertanaman tomat di Kabupaten Jember selama kurun waktu 2010-2014 mencapai luas 1.115 ha yang tersebar di 18 wilayah kecamatan dari 31 kecamatan yang ada di Kabupaten Jember dengan ratarata produksi sebanyak $10.042 \mathrm{kw}$ per tahun dan rata-rata produktivitas sebesar 47,76 $\mathrm{kw} / \mathrm{ha}$ tiap tahunnya. Pada Tabel 1 menunjukkan bahwa perkembangan produksi dan produktivitas tomat di Kabupaten Jember mengalami fluktuasi, sedangkan perkembangan luas panen setiap tahunnya cenderung mengalami penurunan selama periode yang sama.

Tabel 1. Perbandingan Luas Panen, Produksi, Produktivitas Tanaman Tomat Di Kabupaten Jember Tahun 2010-2014

\begin{tabular}{ccccccc}
\hline Tahun & $\begin{array}{c}\text { Luas } \\
\text { Panen } \\
\text { (ha) }\end{array}$ & $\begin{array}{c}\text { Pertum- } \\
\text { buhan } \\
(\boldsymbol{\%})\end{array}$ & $\begin{array}{c}\text { Produksi } \\
(\mathbf{k u})\end{array}$ & $\begin{array}{c}\text { Pertum- } \\
\text { buhan } \\
\mathbf{( \% )}\end{array}$ & $\begin{array}{c}\text { Produktivita } \\
\text { s (ku/ha) }\end{array}$ & $\begin{array}{c}\text { Pertum- } \\
\text { buhan }(\%)\end{array}$ \\
\hline 2010 & 290 & - & 9.581 & - & 33,04 & - \\
2011 & 260 & $-10,34$ & 5.886 & 38,57 & 22,64 & $-31,48$ \\
2012 & 199 & $-23,46$ & 6.052 & 2,82 & 30,41 & 34,34 \\
2013 & 169 & $-15,08$ & 11.632 & 92,20 & 68,83 & 126,32 \\
2014 & 197 & 16,57 & 17.057 & 46,64 & 86,58 & 25,80 \\
\hline Rata-rata & $\mathbf{2 2 3}$ & $\mathbf{- 8 , 0 8}$ & $\mathbf{1 0 . 0 4 2}$ & $\mathbf{2 5 , 7 7}$ & $\mathbf{4 7 , 7 6}$ & $\mathbf{3 8 , 7 4}$ \\
\hline
\end{tabular}

Sumber: Dinas Pertanian Kab. Jember, 2015 
Tabel 1 di atas pada prinsipnya tidak perlu dikhawatirkan secara berlebihan akan menurunnya produksi tomat di Kabupaten Jember. Penggunaan teknologi yang tepat dan ketersediaan dan harga input yang terjangkau serta proteksi harga produk yang terjamin dengan penetapan harga dasar (floor price), maka supplay tomat di Kabupaten Jember akan memenuhi kebutuhan lokal. Selain itu, hasil penelitian Wijaya dan Hadi pada tahun 2014 tentang Analisis efisiensi pemasaran tomat di Kabupaten Jember semakin dapat meyakinkan petani agar tetap berusahatani topat pada musim yang tepat. Sebab hasil penelitian dimaksud mengungkapkan bahwa proses pemasaran komoditas tomat di Kabupaten Jember sepanjang musim tanam 2014 berjalan secara efisien dengan rata-rata harga yang diterima petani tomat atau yang harga yang dibayarkan konsumen mencapai Rp 5.803 .13 per kg dengan share margin mencapai 53.88\% yang berarti produsen petani tomat diuntungkan. Oleh karena itu sangat rasional jika petani masih cenderung memutuskan untuk tetap mengusahakan lahannya untuk ditanami tomat. Berdasarkan fenomena di atas maka tujuan penelitian meliputi: 1) untuk mengukur tingkat produktivitas usahatani tomat dan membandingkan antar skala usahatani, dan 2) untuk mengidentifikasi faktor-faktor yang berpengaruh terhadap produksi usahatani tomat di Kabupaten Jember.

\section{METODE PENELITIAN}

Penelitian ini menggunakan metode deskriptif kuantitatif dengan pendekatan teknik survei (Nazir, 1985). Penelitian ini telah dilaksanakan di Kabupaten Jember yang terhadap lima Kecamatan sampel, yaitu: Ledokombo, Sumberjambe, Ajung, Panti dan Umbulsari secara purposive sampling berdasarkan pertimbangan di wilayah kecamatan tersebut merupakan sentra produksi tomat terluas pertama hingga kelima di Kabupaten Jember. Data yang digunakan adalah data primer dan data sekunder dan telah dilaksanakan pada bulan Februari, tahun 2016. Sampel ditentukan menggunakan metode proportioned random sampling yaitu pengambilan sampel secara acak dan proposional sebesar $20 \%$ petani tomat dari setiap kecamatan dengan total sampel sebanyak 60 orang responden (Singarimbun, 1987). Selain itu untuk menentukan responden strategi pengembangan menggunakan key informan, yaitu seseorang yang dianggap ahli dalam melakukan budidaya dan pemasaran tomat.

\section{Metode Analisis Data}

Untuk menjawab tujuan pertama tentang besernya tingkat produkstivitas dan perbedaan produktivitas antar skala usahatani tomat digunakan digunakan pendekatan 
Average Physical Product (APP) dan uji beda rata-rata menggunakan uji $\mathrm{t}$ dengan formulasi (Boediono, 1982):

di mana:

$$
A P P=\frac{T P P}{X}=\frac{Y}{X}=\frac{f(X)}{X}
$$

$\mathrm{APP}=$ produksi rata-rata per satuan input

$\mathrm{TPP}=$ produksi total

$\mathrm{Y}=$ output

$\mathrm{X}=$ input yang digunakan

Dalam penelitian ini, produktivitas yang diuji terdiri dari produktivitas lahan, produktivitas tenaga kerja, dan produktivitas biaya dan secara matematis diformulasikan sebagai berikut:

$$
A P P_{X_{1}}=\frac{Q}{X_{1}}, A P P_{X_{2}}=\frac{Q}{X_{2}}, A P P_{X_{3}}=\frac{Q}{X_{3}}
$$

di mana:

$\mathrm{APP}_{\mathrm{xi}}=$ produktivitas untuk input $\mathrm{X}_{\mathrm{i}}$

$\mathrm{X}_{\mathrm{i}}=$ input yang digunakan, dimana $\mathrm{X}_{1}=$ lahan, $\mathrm{X}_{2}=$ tenaga kerja, $\mathrm{X}_{3}=$ biaya

produksi

Dalam Pengujian hipotesis ini, secara umum hipotesis yang diajukan adalah:

$\mathrm{H}_{0}$ : Tidak ada perbedaan tingkat produktivitas antar strata luas lahan usahatani tomat, atau $\mu_{1}=\mu_{2}$

Ha: Ada perbedaan tingkat produktivitas antar strata luas lahan usahatani tomat, atau $\mu_{1} \neq \mu_{2}$

Apabila $\mathrm{H}_{0}$ benar, maka kriteria pengambilan keputusan adalah:

$$
t_{\text {hitung }}\left\{\begin{array}{l}
>t_{\text {tabel }}, \text { maka: } \mathrm{H}_{\mathrm{o}} \text { ditolak } \\
\leq \mathrm{t}_{\text {tabel }}, \text { maka: } \mathrm{H}_{\mathrm{o}} \text { diterima }
\end{array}\right.
$$

Jika $t_{\text {hitung }} \leq \mathrm{t}_{\text {tabel }}$, maka dapat dinyatakan bahwa perbedaan antar kedua kelompok skala usahatani tersebut secara statistik tidak signifikan. Apabila terbukti bahwa t-hitung $>$ $\mathrm{t}_{\text {tabel, }}$ maka dari uji $\mathrm{t}$ tersebut dihasilkan kesimpulan memutuskan bahwa $\mathrm{H}_{0}$ ditolak. Guna mengetahui kelompok manakah yang berbeda secara signifikan, maka perlu dilakukan pengujian lebih lanjut dengan Uji Least Significance Different (LSD). Hal ini disebabkan, pengertian secara statistik menggunakan uji t tidak memberikan seberapa besar derajat beda antara rata-rata kelompok yang satu dengan rata-rata kelompok lainnya dan manakah 
yang menunjukkan perbedaan. Untuk itu, digunakan uji t dua arah. Pengujian dilakukan dengan mempergunakan rumus sebagai berikut :

$$
t=\frac{\left(\mu_{1}-\mu_{2}\right)-\left(\bar{x}_{1}-\bar{x}_{2}\right)}{\sqrt{\frac{\left(n_{1}-1\right) S_{1}^{2}+\left(n_{2}-1\right) S_{2}^{2}}{n_{1}+n_{2}-2} \sqrt{\frac{1}{n_{1}}+\frac{1}{n_{2}}}}}
$$

di mana :

$$
=\text { jumlah grup (kelompok yang diperbandingkan }
$$

$S_{1}$ dan $S_{2}=$ total pengamatan

$\bar{n}_{1}$ dan $\bar{x}_{1}$ dan $\bar{x}_{2}=$ derajat bebas antara grup $=(\mathrm{k}-1)$

Menurut Supranto (2001) untuk mengetahui perbandingan produktivitas dengan indikator tertentu (yaitu produktivitas aktual yang dicapai petani dibandingkan dengan produktivitas nasional, produktivitas di tingkat Jawa Timur, dan produktivitas di Kabupaten Jember) digunakan metode uji-Z satu rata-rata dengan rumus sebagai berikut :

$$
Z_{\text {hitung }}=\frac{\bar{x}-\mu_{0}}{\frac{\sigma}{\sqrt{N}}}
$$

di mana :

$Z_{\text {hitung }}=$ harga yang dihitung dan menunjukkan nilai standar deviasi pada

distribusi normal (tabel Z)

$\bar{x}=$ rata-rata nilai yang diperoleh dari hasil pengumpulan data

$\mu_{0}=$ rata-rata nilai yang dihipotesiskan

$\sigma=$ standar deviasi populasi yang telah diketahui

$\mathrm{N}=$ jumlah populasi penelitian

Guna menguji hipotesis kedua, tentang faktor-faktor yang berpengaruh terhadap produksi usahatani tomat, digunakan pendekatan analisis regresi berganda dengan asumsi bahwa bentuk hubungan antara variabel bebas $\left(X_{i}\right)$ dengan variabel terikat $\left(Y_{i}\right)$ merupakan fungsi produksi Cobb-Douglas. Hubungan antara variabel $X$ dan $Y$ tersebut secara matematik dirumuskan sebagai berikut (Sutiarso, 2010) :

$$
Y_{i}=\beta_{0} X_{1_{i}}^{\beta_{1}} X_{2_{i}}^{\beta_{2}} \ldots X_{k}^{\beta_{k}} e^{\mu_{i}}
$$

Diduga faktor-faktor yang berpengaruh terhadap produksi usahatani tomat adalah luas lahan, jumlah tenaga kerja, jumlah bibit, jumlah pupuk, jumlah pestisida, dan pengalaman 
petani bertani tomat. Secara matematik, persamaan taksiran fungsi produksi dengan model regresi adalah:

$$
\hat{Y}=b_{0} X_{1}^{b_{1}} X_{2}^{b_{2}} X_{3}^{b_{3}} X_{4}^{b_{4}} X_{5}^{b_{5}} X_{6}^{b_{6}}
$$

di mana :

$\hat{Y}=$ estimator dari $\mathrm{Y}=$ produksi usahatani tomat $(\mathrm{ku})$

$X_{1}=$ luas lahan (ha)

$X_{2}=$ tenaga kerja $(\mathrm{JKP})$

$X_{3}=$ jumlah bibit (batang)

$X_{4}=$ jumlah pupuk $(\mathrm{kg})$

$X_{5}=$ Jumlah pestisida $(\mathrm{Rp})$

$X_{6}=$ Manajerial (th)

$b_{0}=$ konstanta (intersep).

$b_{1}, b_{2}, \ldots, b_{6}=$ koefisien regresi variabel bebas

Untuk memudahkan pendugaan persamaan tersebut di atas, maka persamaan tersebut diubah menjadi bentuk linier berganda dengan cara melogaritmakan. Persamaan regresi dinyatakan dalam bentuk persamaan logaritma dengan bilangan natural e $=2,71828$, sehingga persamaannya menjadi :

$$
\ln Y_{i}=\operatorname{In} \beta_{0}+\beta_{1} \operatorname{In} X_{1 i}+\ldots+\beta_{k} \operatorname{In} X_{k i}+\mu_{i} \operatorname{In} e
$$

di mana:

$\mathrm{Y}=$ variabel terikat (dependent variabel)

$\mathrm{X}=$ variabel bebas (independent variabel)

$\beta_{0}, \beta_{1}, \ldots, \beta_{k}=$ koefisien regresi

$\mathrm{i}=1,2, \ldots, \mathrm{n}=$ nomor observasi

$\mathrm{j}=1,2, \ldots, \mathrm{k}=$ nomor variabel

Estimasi terhadap bentuk hubungan diatas adalah:

$\ln \hat{Y}=\ln b_{0}+\ln b_{1} X_{1}+\ln b_{2} X_{2}+\ldots+b_{k} \operatorname{In} X_{k}$

di mana:

$\hat{Y}=$ estimator dari $Y$

$b_{0}=$ estimator dari $\beta_{0}$

$b_{1}, b_{2}, \ldots, b_{k}$ masing-masing adalah estimator dari $\beta_{1}, \beta_{2}, \ldots, \beta_{k}$

$u=$ In $\mathrm{Y}-$ In $\hat{Y}=$ estimator dari kesalahan pengganggu $(u)$ 
Pengujian terhadap hipotesis yang diajukan dalam analisis untuk kepentingan estimasi dan interprestasinya meliputi :

a) Pengujian keberartian koefisien regresi parsial secara keseluruhan

$\mathrm{H}_{0}$ : semua koefisien regresi dari faktor-faktor yang berpengaruh terhadap produksi tidak berbeda nyata dengan nol, atau $\quad \beta_{1}=\beta_{2}=\ldots=\beta_{k}=0$

Ha: paling tidak salah satu koefisien regresi dari faktor-faktor yang berpengaruh terhadap produksi berbeda nyata dengan nol, atau $\beta_{j} \neq 0$

Pengujian hipotesis dilakukan secara statistik menggunakan uji $\mathrm{F}$ dengan formulasi sebagai berikut :

$F_{\text {hitung }}=\frac{\text { kuadrat te ngah regre } \mathrm{si}}{\text { kuadrat te ngah sisa }}$

$\left.\begin{array}{l}\text { Jika }\left|F_{h i t}\right| \\ \text { di mana : }\end{array} \begin{array}{l}\leq F_{(\propto ; n-k-1), \text { maka } H_{0} \text { diterima }} \\ >\mathrm{F}_{(\propto ; n-k-1), \text { maka } H_{0} \text { ditolak }}\end{array}\right\}$

$n=$ jumlah observasi

$k=$ jumlah variabel bebas

b) Pengujian keberartian koefisien regresi parsial secara individual Untuk faktor yang berpengaruh positif terhadap produksi yang diajukan hipotesis statistik sebagai berikut :

$H_{0}$ : Koefisien regresi dari faktor produksi yang berpengaruh terhadap produksi tidak berbeda atau sama dengan nol, atau $\beta_{\mathrm{j}}=0$.

Ha: Koefisien regresi dari faktor produksi yang berpengaruh terhadap produksi tidak sama dengan nol, atau $\beta_{\mathrm{j}} \neq 0$.

c) Untuk faktor yang berpengaruh negatif terhadap produksi yang diajukan hipotesis statistik sebagai berikut :

$\mathrm{H}_{0}$ : Koefisien regresi dari faktor produksi yang berpengaruh terhadap produksi tidak berbeda atau sama dengan nol, atau $\beta_{\mathrm{j}} \geq 0$.

Ha: Koefisien regresi dari faktor produksi yang berpengaruh terhadap produksi tidak sama dengan nol, atau $\beta_{\mathrm{j}}<0$. 
Pengujian hipotesis dilakukan secara statistik dengan uji-t sebagai berikut :

$$
t_{\text {hitung }}=\frac{b_{j}-\beta_{j}^{*}}{S_{b_{j}}}
$$

di mana $\beta_{j}^{*}$ adalah $\beta_{j}$ yang sesuai dengan hipotesis nol, dan $S_{b_{j}}$ adalah standar eror dari $b_{j}$

\section{PEMBAHASAN}

$$
\text { Jika }\left|t_{h i t}\right|\left\{\begin{array}{l}
\leq t_{(\propto ; n-k-1)} \text {, maka } H_{0} \text { diterima } \\
\left.>t_{(} \propto ; n-k-1\right) \text {, maka } H_{0} \text { ditolak }
\end{array}\right\}
$$

\section{Produktivitas Usahatani Tomat di Kabupaten}

Dalam proses produksi usahatani tomat pada akhirnya harus dilihat dari produktivitas yang diperoleh petani, hal ini dimaksudkan untuk melihat tingkat produktivitas tomat. Untuk mengetahui rata-rata produktivitas usahatani tomat dapat dilihat pada Tabel 2.

Tabel 2. Rata-rata Produktivitas Lahan, Tenaga Kerja dan Biaya per Hektar

\begin{tabular}{|c|c|c|c|c|}
\hline \multirow{2}{*}{ No. } & \multirow{2}{*}{ Produktivitas } & \multicolumn{2}{|c|}{ Skala Usahatani } & \multirow{2}{*}{$\begin{array}{c}\text { Rata-rata } \\
\text { Total }\end{array}$} \\
\hline & & Sempit & Luas & \\
\hline 1 & Lahan (ku/ha) & 181,48 & 125,76 & 153,62 \\
\hline 2 & Tenaga Kerja (kg/jkp) & 4,998 & 4,810 & 4,906 \\
\hline 3 & Biaya (kg/Rp) & 0,00048 & 0,00046 & 0,00047 \\
\hline
\end{tabular}
Usahatani Tomat di Kabupaten Jember Tahun 2016

Sumber: Data primer Diolah, tahun 2016

Tabel 2 menunjukkan bahwa rata-rata produktivitas lahan usahatani tomat pada musim tanam tahun 2016 di Kabupaten Jember sebesar 153,62 ku/ha. Sementara, untuk rata-rata produktivitas tenaga kerja dan produktivitas biaya masing-masing adalah sebesar 4,906 kg/jkp dan 0,00047 kg/rupiah biaya yang dikeluarkan. Ditinjau dari skala usahatani menunjukkan bahwa produktivitas lahan rata-rata yang dihasilkan oleh petani dengan skala usahatani sempit relatif lebih tinggi jika dibandingkan dengan petani luas. Kondisi ini disebabkan karena petani dengan skala usahatani sempit dapat mengalokasikan input produksinya sesuai dengan kebutuhan tanaman bahkan rata-rata di bawah anjuran. Artinya petani dengan skala usahatani sempit lebih terampil dalam pengelolaan usahatani tomat dibandingkan dengan skala usahatani luas.

Fenomena di atas dapat dibuktikan pada Tabel 2 bahwa produktivitas tenaga kerja skala usahatani sempit relatif lebih tinggi dibandingkan dengan golongan skala usatani luas masing-masing sebesar $4,998 \mathrm{~kg} / \mathrm{jkp}$ dan $4,814 \mathrm{~kg} / \mathrm{jkp}$. Demikan pula rata-rata produktivitas biaya usahatani tomat menunjukkan bahwa skala usahatani luas lebih efisien 
yaitu sebesar $0,00046 \mathrm{~kg} / \mathrm{Rp}$ dibanding dengan skala usahatani sempit yaitu sebesar 0,00048 kg/Rp. Hasil penelitian Nento, Halid, dan Indriani (2013) di Kabupaten Bone Bolango bahwa produktivitas tomat mencapai 29,10 ha/ha. Artinya jika dibandingkan dengan hasil penelitian terdahulu, bahwa tingkat produktivitas usahatani tomat di daerah penelitian ini jauh lebih rendah. Tetapi jika dibandingkan dengan hasil penelitian Fadli (2014) tentang usahatani tomat di Kelurahan Boyaoge Kecamatan Tatanga Kota Palu, maka produktivitas lahan di daerah penelitian ini masih lebih tinggi, dimana tingkat produktivitas usahatani tomat hasil riset oleh Fadli hanya mencapai 13,5 ton/ha. Guna mengetahui perbedaan produktivitas antar skala usahatani tomat di Kabupaten Jember yang menggunakan uji t dua arah tersaji pada Tabel 3 berikut ini :

Tabel 3. Hasil Analisis Uji Beda LSD Terhadap Produktivitas Usahatani Tomat

\begin{tabular}{|c|c|c|c|c|}
\hline No. & Produktivitas & Strata & Signifikansi & Difference \\
\hline \multirow{2}{*}{1.} & \multirow{2}{*}{ Lahan (ku/ha) } & Sempit & \multirow{2}{*}{$0,000^{* * *}$} & \multirow{2}{*}{55,72303} \\
\hline & & Luas & & \\
\hline \multirow{2}{*}{2.} & \multirow{2}{*}{ Tenaga Kerja (kg/jkp) } & Sempit & \multirow{2}{*}{$0,584^{\mathrm{ns}}$} & \multirow{2}{*}{0,18424} \\
\hline & & Luas & & \\
\hline \multirow{2}{*}{3.} & \multirow{2}{*}{ Biaya (kg/Rp) } & Sempit & \multirow{2}{*}{$0,309^{\mathrm{ns}}$} & \multirow{2}{*}{$-0,00001700$} \\
\hline & & Luas & & \\
\hline \multicolumn{5}{|c|}{$\begin{array}{l}\text { Keterangan: Pengujian hipotesis menggunakan uji-t dua arah, di mana }{ }^{* * *} \text { menyatakan } \\
\text { signifikan masing-masing pada tingkat kepercayaan } 99 \% \text {, dan ns: tidak signifikan pada } \\
\text { taraf kepercayaan } 90 \%\end{array}$} \\
\hline
\end{tabular}

Berdasarkan uji t dua arah yang ditunjukkan pada Tabel 3, dapat diketahui bahwa perbandingan produktivitas antar skala luas usahatani tomat antara lain: 1) Perbandingan produktivitas lahan tomat di antara skala usatani menunjukkan bahwa perbedaan sangat signifikan pada taraf kepercayaan $99 \%$ antara golongan petani sempit dengan luas. Kondisi tersebut disebabkan karena jumlah input yang digunakan relatif tidak sama dalam berusahatani tomat. Produktivitas lahan untuk skala usahatani sempit lebih besar dibandingkan dengan skala usahatani luas. Hal ini kemungkinan disebabkan skala usahatani lebih intensif dalam mengatur jarak tanam, penggunaan sarana produksi dan penggunaan tenaga kerjanya, 2) Berdasarkan produktivitas tenaga kerja antar skala usahatani menunjukkan bahwa skala usahatani sempit lebih besar dalam penggunaan 
tenaga kerja, yaitu sekitar 4,998 kg/jkp, sementara untuk skala usahatani luas sekitar 4,810 $\mathrm{kg} / \mathrm{jkp}$. Produktivitas tenaga kerja di antara strata petani menunjukkan perbedaan yang tidak signifikan pada taraf uji 10\% antar skala usaha, dan 3) Bahwa penggunaan biaya produksi oleh petani berskala sempit lebih besar dibandingkan dengan skala luas yaitu masing-masing sebesar Rp 37.590.282/ha dan Rp 27.650.027,- /ha. Artinya besarnya biaya produksi usahatani tomat di daerah penelitan ini jauh lebih tinggi dibandingkan dengan hasil riset oleh Fadli (2014) di Kota Palu yaitu sebanyak Rp 22.977.700,17/ha.

\section{Faktor-Faktor Yang Berpengaruh Terhadap Produksi Usahatani Tomat}

Faktor Produksi sering pula disebut dengan korbanan produksi, karena faktor produksi tersebut dikorbankan untuk menghasilkan produksi. Untuk menghasilkan suatu produk, maka diperlukan pengetahuan hubungan antara faktor produksi (input) dan produk (output). Dalam usahatani tomat faktor-faktor produksi diduga berupa luas lahan, tenaga kerja, bibit, pupuk, pestisida dan manajerial sebagaimana yang tampak pada Tabel 4.

Tabel 4. Hasil Analisis Regresi Fungsi Produksi Cobb-Douglas Usahatani Tomat

\begin{tabular}{lccc}
\hline \multicolumn{1}{c}{ Variabel } & Parameter & Koefisien Regresi & T \\
\hline Konstanta & $\beta_{0}$ & $-5,933$ & $2,428^{* *}$ \\
Luas Lahan $\left(\mathrm{X}_{1}\right)$ & $\beta_{1}$ & $-0,483$ & $2,827^{* *}$ \\
Tenaga Kerja $\left(\mathrm{X}_{2}\right)$ & $\beta_{2}$ & 0,647 & $4,278^{* * *}$ \\
Bibit $\left(\mathrm{X}_{3}\right)$ & $\beta_{3}$ & 0,539 & $4,890^{* * *}$ \\
Pupuk $\left(\mathrm{X}_{4}\right)$ & $\beta_{4}$ & 0,063 & $0,823^{\mathrm{ns}}$ \\
Pestisida $\left(\mathrm{X}_{5}\right)$ & $\beta_{5}$ & $-0,045$ & $0,726^{\mathrm{ns}}$ \\
Manajerial $\left(\mathrm{X}_{6}\right)$ & $\beta_{6}$ & $-0,166$ & $0,838^{\mathrm{ns}}$ \\
\hline Std. Error Estimasi & $\mathrm{Se}$ & 0,22028 & \\
R Square & $\mathrm{R}^{2}$ & 0,786 & \\
Adjusted R Square & $\mathrm{R}^{2}$ & 0,762 & \\
R Berganda & $\mathrm{R}$ & 0,886 & \\
F-Ratio & & $32,494^{* * *}$ & \\
$\sum \beta_{j}$ & & 0,555 & \\
$\mathrm{n}$ & & 60 &
\end{tabular}

Keterangan: Pengujian hipotesis menggunakan uji-t dua arah, di mana ${ }^{* * *},{ }^{* * *}$ menyatakan signifikan masing-masing pada tingkat kepercayaan 95\%, 99\%, dan ns: tidak signifikan pada taraf kepercayaan $90 \%$

Sumber: Data primer diolah, tahun 2016 
Berdasarkan hasil analisis regresi fungsi produksi maka, persamaan fungsi produksi linier usahatani tomat dapat dirumuskan:

$\ln Y=-5,933 \quad-0,483 \quad \ln X_{1}+0,647 \quad \ln X_{2}+0,539 \quad \ln X_{3}+0,063 \quad \ln X_{4}-\quad 0,045 \quad \ln X_{5}-0,166 \quad \ln X_{6}$

Persamaan linier tersebut dimasukkan sehingga fungsi produksi cobb-douglas usahatani tomat sebagai berikut:

$$
Y=0,003 X_{1}^{-0,483} X_{2}^{0,647} X_{3}^{0,539} X_{4}^{0,063} X_{5}^{-0,045} X_{6}^{-0,166}
$$

Faktor-faktor yang diduga berpengaruh terhadap produksi tomat disajikan pada Tabel 3.3. Dari tabel tersebut menggambarkan bahwa produksi dalam usahatani tomat diasumsikan dipengaruhi oleh faktor: (1) luas lahan; (2) tenaga kerja; (3) bibit; (4) pupuk; (5) pestisida; (6) manajerial. Faktor luas lahan, tenaga kerja, bibit, pupuk, pestisida, dan manajerial secara bersama-sama berpengaruh secara signifikan terhadap produksi usahatani tomat. Hal ini dapat dilihat dari nilai F-hitung $(=32,494)$ yang sangat signifikan pada taraf uji $1 \%$.

Dilihat dari nilai koefisien determinasi $\left(\bar{R}^{2}\right)$ yang sebesar 0,762 menunjukkan bahwa variabel bebas yang dimasukkan ke dalam model dapat mengidentifikasikan variasi variabel dependen (produksi) secara baik sekitar 76,2\%. Hanya 23,8\% yang dijelaskan oleh faktor lain yang tidak masuk ke dalam model di antaranya adalah curah hujan dan iklim. Apabila dilihat dari nilai koefisien regresi parsial yang menggunakan full-model, maka faktor produksi luas lahan, tenaga kerja dan bibit berpengaruh secara signifikan terhadap produksi usahatani tomat. Sementara pengaruh dari variabel pupuk, pestisida dan manajerial berpengaruh tidak signifikan sebagaimana diuraikan secara detail dalam pembahasan berikut.

Pada fungsi produksi tomat, luas lahan mempunyai pengaruh yang negatif dan signifikan pada uji taraf 5\% yang berarti semakin luas lahan garapan usahatani tomat yang dikelola, maka semakin menurun produksi yang diperolehnya. Hal ini mengindikasikan bahwa penggunaan variabel luas lahan pada proses produksi berada pada daerah tidak rasional karena secara teknis penggunaan lahan terlalu luas sehingga petani kurang dapat mengontrol dengan baik. Adapun secara ekonomis dapat diinterpretasikan bahwa jika luas lahan ditambah sebesar $1 \%$ akan mengakibatkan tingkat produksi petani justru mengalami penurunan sebesar $0,483 \%$ dan sebaliknya dengan asumsi cateris paribus. Hal ini sejalan dengan hasil penelitian tentang Analisis Usahatani Tomat di Kecamatan Tawaili 
Kabupaten Donggala oleh Lamusa (2004) bahwa faktor produksi lahan berpengaruh nyata terhadap usahatani tomat pada taraf nyata $1 \%$, namun berpengaruh positif.

Pengaruh faktor tenaga kerja berpengaruh positif terhadap produksi usahatani tomat secara signifikan pada taraf uji $1 \%$. Artinya semakin banyak tenaga kerja yang digunakan petani sebesar $1 \%$, maka semakin tinggi produksi yang diperoleh nantinya, yaitu sebesar $0,647 \%$ dan sebaliknya dengan asumsi cateris paribus. Adapun secara teknis rata-rata penggunaan tenaga kerja oleh petani sudah berada pada daerah rasional atau sudah tergolong efisien. Kondisi ini sesuai dengan hasil penelitian tentang Analisis Usahatani Tomat di Kecamatan Tawaili Kabupaten Donggala oleh Lamusa (2004) bahwa faktor produksi tenaga kerja berpengaruh nyata terhadap usahatani tomat pada taraf nyata $5 \%$, namun berpengaruh negatif. Selanjutnya jika dirujuk kepada hasil penelitian Sujana (2010) tentang "Analisis Pendapatan dan Faktor-Faktor Produksi yang Mempengaruhi Usahatani Tomat di Desa Lebak Muncang, Kecamatan Ciwidey, Kabupaten Bandung”, maka kondisi ini relatif sejalan. Hasil riset Sujana tersebut bahwa penaga kerja berpengaruh positif terhadap produksi tomat, pada fungsi produksi petani tomat anggota kelompok tani tenaga kerja memiliki nilai koefisien sebesar 0,518 , yang berarti setiap penambahan penggunaan tenaga kerja sebesar satu persen akan meningkatkan jumlah produksi sebesar 0,518 persen cateris paribus. Sedangkan untuk petani non kelompok tani nilai koefisien tenaga kerja adalah 1,256, berarti setiap penambahan tenaga kerja sebesar satu persen, maka akan menyebabkan kenaikan peroduksi sebesar 1,256 persen. Berdasarkan hasil penelitian di lapangan, bahwa tenaga kerja memiliki peranan yang penting terkait dengan aktivitas pemeliharaan tanaman tomat yang memang membutuhkan perhatian khusus terutama pada saat pemotongan tunas, penalian batang tomat, pemberantasan hama serta panen, karena pada aktivitas tersebut penggunaan tenaga kerja cukup intensif.

Faktor produksi bibit berpengaruh positif dan secara teknis berada pada daerah rasional atau sudah efisien dengan nilai koefisien regresi 0,539 dan signifikan pada taraf uji 1\%. Meskipun demikian di daerah penelitian ini masih bisa dimungkinkan untuk meningkatkan penggunaan bibit sesuai dengan anjuran pemerintah untuk mencapai produksi optimum dan profit yang maksimum. Secara ekonomis dapat diartikan bahwa setiap penambahan jumlah bibit tomat sebesar $1 \%$, maka produksi yang diperoleh petani akan meningkat rata-rata sekitar $0,539 \%$ dan sebaliknya denga asumsi cateris paribus. Kondisi penggunaan bibit di daerah penelitian ini sejalan dengan kondisi hasil penelitian 
Sujana (2010) di Desa Lebak Muncang, Kecamatan Ciwidey, Kabupaten Bandung”. Hal ini ditunjukkan bahwa nilai koefisien regresi benih adalah 0,331 , dimana nilai ini nyata pada selang kepercayaan 95 persen.

Benih memiliki nilai koefisien yang positif serta berpengaruh nyata pada produksi tomat, artinya apabila penggunaan benih sebagai salah satu faktor produksi ditambahkan sebanyak satu persen, maka produksi tomat tomat akan meningkat sebesar 0,331 persen dengan asumsi cateris paribus. Tingkat kesalahan dari pendugaan ini adalah sebesar lima persen, dimana penggunaan benih ini dapat dikatakan cukup responsif terhadap produksi tomat yang dihasilkan. Tetapi hasil penelitian di daerah ini kondisi pengaruh penggunaan bibit tomat terhadap produksi tomat berbeda dengan hasil riset di wilayah Kecamatan Tawaili Kabupaten Donggala oleh Lamusa (2004) dimana penggunaan bibit tidak berpengaruh nyata terhadap produksi usahatani tomat pada taraf nyata $10 \%$.

. Pengaruh faktor penggunaan pupuk berpengaruh positif, akan tetapi secara statistik tidak signifikan pada taraf uji $10 \%$. Artinya apabila penggunaan pupuk ditambah sebesar $1 \%$, maka meningkatkan produksi tomat sebesar $0,063 \%$ dan sebaliknya dengan asumsi cateris paribus meskipun pengarunya tidak nyata. Secara teknis pengguaan faktor produksi pupuk sudah efisien (berada di daerah rasional), namun masih bisa dimungkinkan untuk meningkatkan penggunaan pupuk untuk mencapai produksi optimum dan profit maksimum. Jika merujuk pada hasil penelitian Lamusa (2004) di wilayah Kecamatan Tawaili Kabupaten Donggala, maka ada perbedaan dan persamaanya. Persamaannya poenggunaan pupuk sama-sama berdampak positif, sedangkan perbedaannya adalah hasil penelitian di daerah ini dampaknya non signifikan dan hasil riset Lamusa justru signifikan pada taraf nyata $10 \%$. Selanjutnya jika merujuk pada hasil penelitian Sujana (2010) di Desa Lebak Muncang, Kecamatan Ciwidey, Kabupaten Bandung” menunjukkan bahwa penggunaan pupuk N, P dan K berdampak signifikan pada produksi usahatani tomat pada taraf nyata masing-masing $\alpha=99 \%, \alpha=95 \%$, dan $\alpha=99 \%$, tetapi koefisien regresinya masing-masing bertanda positif, positif dan negatif.

Faktor penggunaan pestisida berpengaruh negatif dan tidak signifikan pada taraf uji $10 \%$ besar koefisien regresi sebesar $-0,045$ terhadap produksi tomat. Artinya semakin banyak petisida yang digunakan terhadap usahatani tomat sebesar $1 \%$, maka produksi tomat cenderung menurun sebesar 0,045\% dan sebaliknya dengan asusmi cateris paribus. Koefisien regresi pada faktor produksi pestisida juga menggambarkan elastisitas produksi, 
sehingga hal ini mengindikasikan bahwa penggunaan variabel pestisida pada fungsi produksi berada pada daerah tidak rasional atau sudah tidak efisien lagi karena rata-rata petani menggunakan pestisida jauh melebihi rekomendasi. Pada posisi penggunaan faktor produksi pestisida tersebut telah berlaku The Law of Diminishing Returns, sehingga jika petani masih menambah penggunaan jenis input ini, maka total produksinya (TPP) justru semakin berkurang, apalagi produk marginalnya (MPP) dapat dipastikan negatif $(<0)$.

Selanjutnya jika dikomparasi dengan hasil penelitian Sujana (2010) di Desa Lebak Muncang, Kecamatan Ciwidey, Kabupaten Bandung dapat ditunjukkan bahwa nilai koefisien regresi pestisida cair adalah -0,333, dimana nilai ini nyata pada selang kepercayaan 95 persen. Pestisida cair memiliki nilai koefisien yang negatif serta berpengaruh nyata pada produksi tomat, artinya apabila penggunaan pestisida cair sebagai salah satu faktor produksi ditambahkan sebanyak satu persen, maka produksi tomat tomat akan menurun sebesar 0,331 persen cateris paribus, dan tingkat kesalahan dari pendugaan ini adalah sebesar lima persen. Kondisi di lapangan menunjukkan bahwa pestisida ini sangat penting dalam kegiatan budidaya tanaman tomat. Pestisida cair ini terdiri dari insektisida dan fungisida dalam bentuk cair, dengan satuan liter.

Selain itu, hasil penelitian Sujana (2010) di Desa Lebak Muncang, Kecamatan Ciwidey, Kabupaten Bandung ditunjukkan bahwa nilai koefisien regresi dari pestisida padat adalah 0,036, dan nilai ini tidak berpengaruh nyata pada selang kepercayaan 95 persen. Nilai koefisien regresi ini tidak berpengaruh nyata, berarti bahwa walaupun penggunaan pestisida padat ditambahkan ataupun dikurangkan dalam penggunaannya, maka tidak akan berpengaruh sama sekali terhadap jumlah produksi tomat. Kondisi di lapangan menunjukkan bahwa petani tomat anggota kelompok tani lebih banyak menggunakan pestisida cair dibandingkan dengan pestisida padat, karena pestisida lebih banyak yang berbentuk cair dibandingkan dengan berbentuk padat.

Faktor manajemen (kemampuan petani dalam mengelola usahataninya) berpengaruh negatif dengan nilai koefisien regresi -0,166 dan tidak signifikan pada taraf uji $10 \%$ terhadap produksi usahatani tomat. Kondisi ini disebabkan karena tidak ada perbedaan umur, tingkat pendidikan, dan pengalaman berusahatani yang signifikan diantara petani tomat. Padahal secara teori menurut pendapat Muhyarto (1994) dan Soekartawi (2005) bahwa faktor manajemen dapat berpengaruh terhadap produksi usahatani karena faktor ini menunjukkan tingkat keterampilan petani dalam mengelola usahataniya. 
Selain faktor manajemen dapat didekati dengan umur, tingkat pendidikan, dan pengalaman berusahatani, juga dapat menggunakan pendekatan jumlah frekuensi tingkat kehadiran petani dalam pelatihan, penyuluhan, studi banding, magang, intensitas kehadiran PPL dan lain-lain. Faktanya beberapa variabel yang disebutkan terakhir ternayata memang tidak diukur dalam penelitian ini karena memang di lapangan tidak ada data yang dapat digali dalam beberapa dekade terakhir ini. Kelembagaan petani (kelompok/Gapoktan dan PPl tidak pernah ada interaksi dengan kegiatan usahatani tomat. Jika interaksi dimaksud benar-benar terjadi di lapangan, maka faktor manajemen cenderung signifikan pengaruhnya terhadap produksi usahatani tomat. Adapun dalam penelitian ini pengaruh variabel ini berdampak negatif terhadap produksi usahatani tomat, hal ini disebabkan semakin tinggi tingkat manajemen yang dimliki, petani di daerah penelitian semakin banyak melakukan trial and error untuk menerapkan berbagai variasai teknologi, sehingga mengakibatkan justru produksinya cenderun semakin menurun.

Dalam fungsi produksi Cobb-Douglas dikenal dengan istilah return to scale yang menunjukkan besarnya perubahan output akibat perubahan secara proporsional dari fungsi produksi yang digunakan untuk mengetahui apakah kegiatan dari suatu usaha yang diteliti tersebut mengikuti kaidah Increasing, Constant atau Decreasing return to scale. Besaran elastisitas menunjukkan besaran return to scale yaitu penjumlahan koefisien regresi dari fungsi produksi Cobb-Douglas. Dengan demikian dapat dinyatakan bahwa fungsi produksi usahatani tomat di Kabupaten Jember Decreasing Return to Scale karena jumlah koefisien regresi kurang dari satu $(=0,56)$. Artinya, apabila proporsi penggunaan faktor produksi naik sebesar $1 \%$ maka produksi akan turun kurang dari sebesar $1 \%$.

\section{KESIMPULAN}

1. Produktivitas lahan usahatani tomat di Kabupaten Jember adalah $153,662 \mathrm{ku} / \mathrm{ha}$ dan produktivitas tenaga kerja sebesar 4,906 kg/JKP sedangkan produktivitas biaya sebesar $2.252 \mathrm{Rp} / \mathrm{kg}$. Tidak ada perbedaan produktivitas tenaga kerja maupun biaya produksi antara petani berskala usahatani sempit dengan petani luas. Akan tetapi, produktivitas lahan antara berskala usahatani sempit dengan petani luas, menunjukkan adanya perbedaan yang sangat signifikan pada taraf kepercayaan $99 \%$.

2. Faktor-faktor yang berpengaruh signifikan terhadap produksi adalah luas lahan, tenaga kerja dan bibit, sedangkan faktor pupuk dan pestisida berpengaruh tidak nyata terhadap produksi usahatani tomat di Kabupaten Jember. 


\section{DAFTAR PUSTAKA}

Badan Intelijen Negara, 2012. Prediksi dan Tantangan Sektor Pertanian Indonesia

Tahun 2013. http://bin.go.id/prediksi-dan-tantangan-sektor-pertanian-indonesiatahun-2013.htm, Diakses tanggal 20 November 2015.

BPS. 2015. Luas Panen dan Produksi Tomat. Badan Pusat Statistik Indonesia, Jakarta.

Boediono. 1982. Ekonomi Mikro. Yogyakarta: BPFE.

Dinas Pertanian Kabupaten Jember, 2015. Produksi Sayuran di Kabupaten Jember.

Kantor Dinas Pertanian Kabupaten Jember, Jember. https://publikasi.polije.ac.id. Diakses Tanggal 25 Agustus 2016.

Fadli, S., 2014. Analisis pendapatan dan kelayakan Usahatani Tomat di Kelurahan Boyaoge Kecamatan Tatanga Kota Palu. Jurnal AGROLAND. 21 (01): Hal 45 - 48. Kementerian Pertanian RI, 2015. Rencana Strategis Kementerian Pertanian 2015-2019, Jakarta. www.pertanian.go.id/file/RENSTRA_2015-2019. Diakses Tanggal 21 Agustus 2016.

Lamusa, A., 2004. Faktor-Faktor yang Mempengaruhi Produksi Tomat (Suatu Kasus di Wilayah Kebun Kopi) Kecamatan Tawaili Kabupaten Donggala. J-Agrisains. 5 (1): Hal. $35-42$.

Mubyarto. 1994. Pengantar Ekonomi Pertanian. Jakarta: LP3ES.

Nazir, M., 1985. Metode Penelitian. Jakarta: Ghalia.

Nento, V.Z., Halid, A., dan Indriani, R., 2013. Analisis Keuntungan usahatani Tomat di Kecamatan Tilongkabila Kabupaten Bone Bolango. www.kim.ung.ac.id. Diakses pada tanggal 14 Februari 2016.

Singarimbun dan Effendi, S., 1987. Metode Penelitian Survei. Jakarta: LP3ES.

Soekartawi, 2005. Agribisnis Teori dan Aplikasi. Edisi Revisi. Jakarta: PT. Raja Grafindo Persada.

Supranto, J., 2001. Statistik Teori dan Aplikasinya. Jakarta: Erlangga.

Sutiarso, E., 2010. Analisis Regresi Sederhana, Jurusan Sosial Ekonomi Pertanian, Fakultas Pertanian, Universitas Muhammadiyah Jember, Jember.

Sujana, W., 2010. Analisis Pendapatan dan Faktor-Faktor Produksi yang Mempengaruhi Usahatani Tomat di Desa Lebak Muncang, Kecamatan Ciwidey, Kabupaten Bandung. Skripsi. Departemen Agribisnis, Fakultas Ekonomi dan Manajemen, Institut Pertanian Bogor. http://repository.ipb.ac.id/jspui/bitstream. Diakses pada tanggal 15 Februari 2016. 
Jurnal Relasi, Vol. XIV, No. 02, Juli 2018

Wijaya, I., dan Hadi, S., 2014. Analisis Efisiensi Pemasaran Tomat (Lycopersicon esculentum mill) Berbasis Jaring Laba-Laba di Kabupaten Jember. Prosiding Seminar Nasional dengan Tema "Pembangunan Nasional Berbasis Teknologi dan Sumber Daya Lokal” oleh Fakultas Pertanian Universitas Muhammadiyah Jember pada tanggal 19 Agustus 2014 dengan No. ISBN: 9-78602-711-480-9 Halaman: $49-61$. 